\title{
分岐管を走行できるへビ型ロボットの提案
}

\section{Proposal of a Snake type In-Pipe Mobile Robot Passable T-junction}

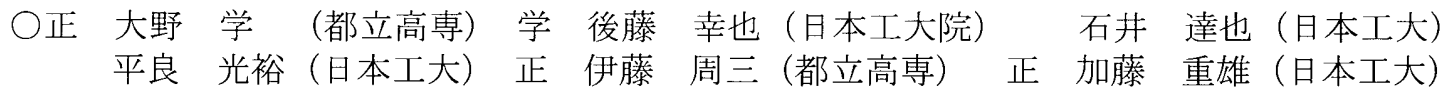

\footnotetext{
Manabu ONO, Tokyo Metropolitan College of Industrial Technology, Shinagawa, Tokyo, 140-0011

Yukiya GOTO, Nippon Institute of Technology, Miyashiro, Saitama, 345-8501

Tatsuya ISHII, Nippon Institute of Technology

Mitsuhiro TAIRA, Nippon Institute of Technology

Shuzo ITO, Tokyo Metropolitan College of Industrial Technology

Shigeo KATO, Nippon Institute of Technology
}

\begin{abstract}
We have many small diameter pipes that are cooling pipes for atomic power stations, boiler pipes, and gas or water pipe lines. They must be periodically inspected in order to protect the accident previously. Diameters and $\mathrm{T}$-junctions of these pipes are different at the place where pipes change from the main to the branch. The inspection microrobot for these pipes must move different diameter and $\mathrm{T}$-junction. The fabricated mobile microrobot was confirmed to move in different diameter pipes and T-junction whose diameters are between $44 \mathrm{~mm}$ and $90 \mathrm{~mm}$. Its speed was $24 \mathrm{~mm} / \mathrm{s}$.
\end{abstract}

Key words: In-pipe, Mobile Robot, Bellows, Snake, Pneumatic Actuators

\section{1.}

ガス管や水道管などの都市生活を支える配管は，配管内部 の傷や腐食によ, 内部の流体漏れに起因する様々な被害が報 告されている。これら配管の設置場所は，建物の壁の間や地 中埋設などであり，人間による外部からの接近，検查が困難 である。

そのため，著者らはこれまで配管内部からの検査を目的と し,「出力／重量」比で有利な空気圧アクチュエータを用い, ミミズやシャクトリムシの運動を摸擬した管内走行ロボット [1] [2] を提案している.これらの検查ロボットは, 内径 $80 \mathrm{~mm}$ の内径が一定である管を $100 \mathrm{~m}$ 以上の長距離走行できること を目的に設計している.そのため, ガス管や水道管などに存 在する本管と支管の内径が異なる箇所や， $\mathrm{T}$ 字分岐管の走行 は不可能である。

内径の異なる管や $\mathrm{T}$ 字分岐管の通過ができるロボットを 実現するため，へビの管内や縦穴等の移動方法であるアコー ディオン運動を模倣した管内走行ロボットを提案している [3][4].へビ型の管内走行ロボットは, アコーディオン運動 を実現するため，3 個の体節から構成される．前・後ろの体 節は屈曲できるアクチュエータから構成され，体節を屈曲さ せることで管を保持できるブレ一キ機構としている．中心の 体節はロボットの駆動に必要な変位を与えるアクチュエータ から構成され，駆動機構として構成される.

今回，前後のブレーキ機構の動作タイミングを制御するこ とにより， $\mathrm{T}$ 字分岐管において希望する方向に走行できるこ とが確認できた。 また, 基本走行特性として, 内径 $54 \mathrm{~mm}$ か ら 90mm のアクリル管内での走行が確認でき, 本ロボット の配管適応範囲がわかり，これらの配管を組み合わせた内径 の異なる箇所の通過も確認できたので報告する.

\section{2. ロボットの棈造}

図 1 に試作した管内走行ロボットの構造を示す。本ロボッ 卜は前部と後部 2 個のブレーキ機構, 変位機構, 空気供給チ ューブから構成される. 変位機構には外径 $33 \mathrm{~mm}$, 自然長 50mmの NBR (Nitrile Butyl Rubber) 製ベローズから構成され る。その前後にはブレーキ機構が取り付けられる。ブレーキ 機構の先端と，ブレーキ時に管と接触する部分には，ベロー

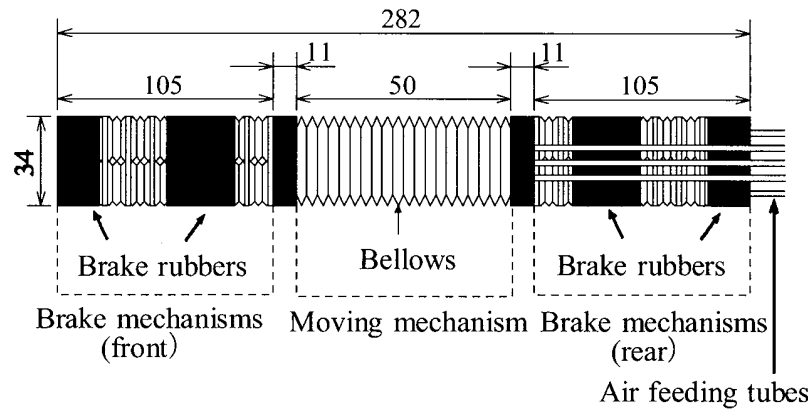

Fig. 1 Structure of in-pipe mobile robot

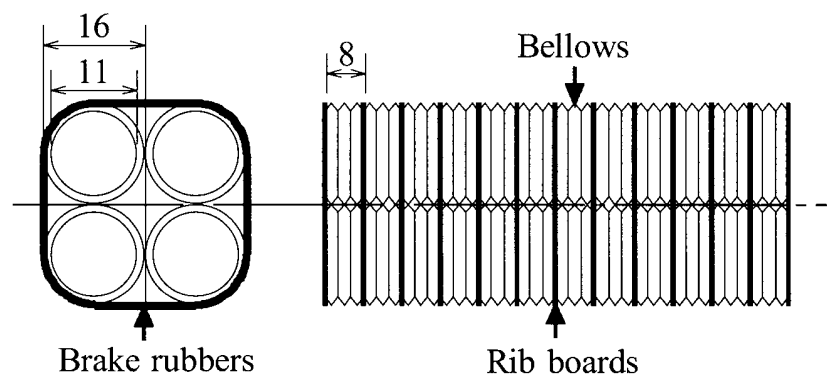

Fig. 2 Structure of brake mechanism

ズより管との摩擦係数が大きいブレーキゴムを取り付けてい る。これは，管との摩擦力を向上させ，ブレーキ力を向上さ せるためである。

ブレーキ機構の詳細な構造を図 2 に示す.ブレーキ機構は, 外径 $16 \mathrm{~mm}$ の NBR 製ベローズ 4 個を 2 行 2 列のマトリクス 状に配置している．また，4 個のベローズを接続するための 肋骨板が $8 \mathrm{~mm}$ 間隔で取り付けられる，肋骨板は，筋肉の役 割をするそれぞれのベローズが正常な伸縮運動ができ,また， 
ブレーキ機構の岡性を高める役割をしている。このような構 造とすることで, ブレーキ機構の片側 2 個のベローズに正圧 力を, 残りの 2 個に負圧力を供給し，収縮状態のベローズが 伸張状態のベローズを引っ張り，バイメタルのような動作を するため，ブレーキ機構は屈曲することができる。

各ベローズには空気圧を供給するための空気供給チューブ が接続される。空気供給チューブはロボットの動作に支障の ない位置に接続される.

\section{3. ロボットの基本動作}

\section{1 ヘビのアコーディオン正動}

へビは，たて穴等の狭い通行や木登りなどでは，一般的に アコーディオン運動をするといわれている．垂直管内でのへ ビの移動動作を観察し, それを安易図にしたものを図 3 に示 す.

アコーディオンのように交互にからだを S 字に曲げ，管 との摩擦を発生させている状態をステップ 0 とする.

ステップ 1：頭部を進行方向に伸ばし，頭部ブレーキを外す. ステップ 2：上半身を伸ばし進行方向へ移動する.

ステップ 3: 頭部を管壁に当て, 前方の体を屈曲させ, 身体 を支える。

ステップ 4: 下半身を屈曲させた状態から伸張させ，下半身 のブレーキを外す.

ステップ 5: 下半身をたぐり寄せるようにして，下半身を全 身させる。

ステップ 6: 全身を S 字に曲げ管壁に押し付け，摩擦を発生 させる。

この一連の動作でへビは垂直に設置した管内を移動するこ

\section{とができることを確認した。}

\section{2 口ボットの基本走行怔作}

ロボットを構成する各べローズの压力を変化させることで 変位機構を伸縮させたり, ブレーキ機構を屈曲させることが できる。

動作順序を図 4 に示す. 前部ブレーキ機構と後部ブレーキ 機構を屈曲させ, 変位機構のベローズが収縮している状態を 初期状態ステップ0とする.

ステップ 1 : 前部ブレーキ機構のすべてのベローズに負圧力 を与える。前部ブレーキ機構は屈曲を解除し， 収縮状態となる。

ステップ 2 : 変位機構のベローズに正圧力を与え, ベローズ を伸張させる。このとき, 後部ブレーキ機構は 屈曲してブレーキ状態であり，前部ブレーキ機 構は収縮してブレーキ解除状態であるため，口 ボットの前側が進行方向に進む.

ステップ 3: 前部ブレーキ機構のベローズ内圧力を切り替 え, 屈曲させる. 屈曲したブレーキ機構は摩擦 力を発生するため, ブレーキ状態となる.

ステップ 4 : 後部ブレーキ機構のすべてのベローズに, 負压 力を与え, 収縮させる。後部ブレーキ機構はブ レーキ解除状態となる。

ステップ 5 : 変位機構のベローズに負圧力を与え, 収縮させ る。このとき，前部ブレーキ機構はブレーキ状 態であり，後部ブレーキ機構はブレ一キ解除状 態であるため, ロボットの後側が進行方向に進 む.

ステップ 6 : 後部ブレーキ機構のベローズ内圧力を切り替え 屈曲させる. 動作としてはステップ 0 と同様と なる。

これら動作を繰り返すことにより，ロボットは前進するこ とができる。これらの動作に要する時間をサイクルタイムと する。

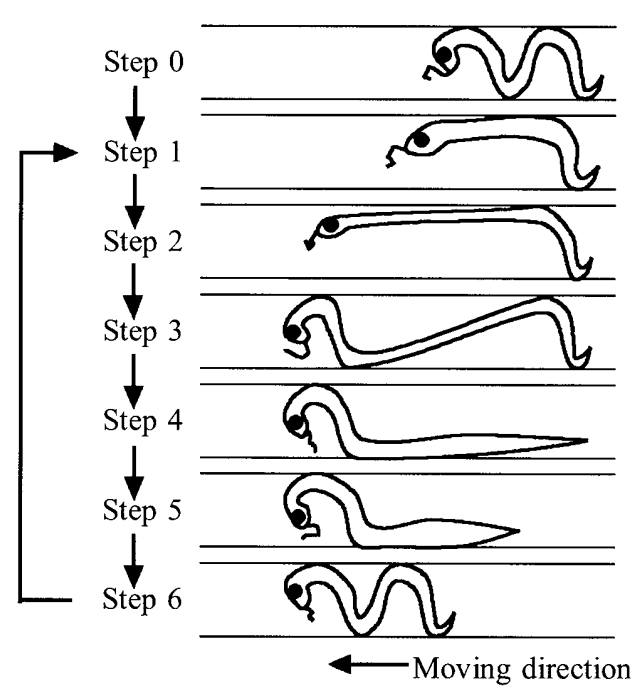

Fig. 3 Accordion movement of a snake

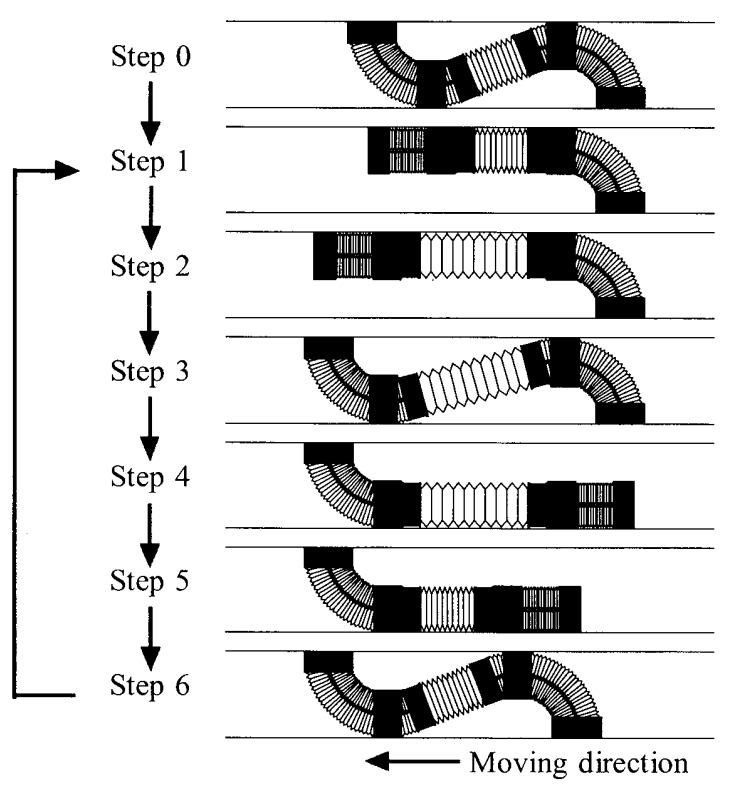

Fig. 4 Moving principle of robot

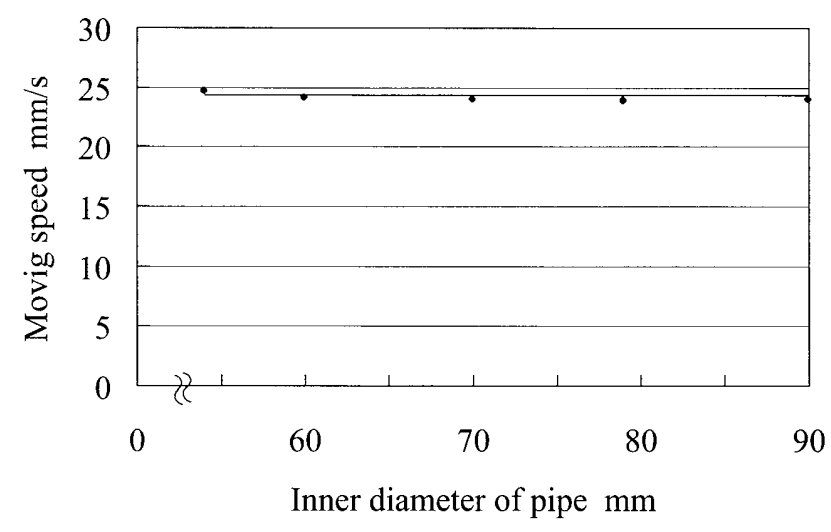

Fig. 5 Moving speed characteristics 


\section{4. 走行英鏂}

\section{1 基本走行实験}

内径 $54 \mathrm{~mm}, 60 \mathrm{~mm}, 70 \mathrm{~mm}, 79 \mathrm{~mm}, 90 \mathrm{~mm}$ のアクリル管 を用意し，走行速度を計測した。実験条件は，ロボットの動 作サイクルタイムを 4.0s とし, 供給圧力はベローズを伸張 させる正圧力を $50 \mathrm{kPa}$ とし, 収縮させる負圧力を- $80 \mathrm{kPa}$ と した。

走行速度の実験結果を図 5 に示す．走行速度は管の内径に 依存することなく, 平均 $24 \mathrm{~mm} / \mathrm{s}$ であることが確認できた。 また, 走行できる最小内径の管は, ロボットの寸法より $54 \mathrm{~mm}$ であり，最大の管は $90 \mathrm{~mm}$ であることがわかった。

アクリル管を垂直方向に配置し, ロボットに荷重を与え, ロボットの牵引力を計測した。実験条件は走行速度実験と同 様である. 铑引力の実験結果を図 6 に示す.内径 $54 \mathrm{~mm}$ の 管において $6.4 \mathrm{~N}$ であり，内径 $90 \mathrm{~mm}$ の管においては $0.5 \mathrm{~N} て ゙$ あった。率引力は管の内径に依存し，管の内径が大きくなる とほぼ比例して低下していくことが確認できた。

\section{2 内经の異なる段差のある管の走行英験}

内径 $54 \mathrm{~mm}, 60 \mathrm{~mm}, 70 \mathrm{~mm}, 79 \mathrm{~mm}, 90 \mathrm{~mm}$ のアクリル管 を 2 本ずつ組夕合わせ，図 7 に示す段差の存在する実験用走 行管を製作した。実験条件は，ロボットの動作サイクルタイ ムを $4.0 \mathrm{~s} と し$, 供給圧力はベローズを伸張させる正圧力を $50 \mathrm{kPa}$ とし，収縮させる負圧力を-80kPa とした。ロボットが アコーディオン運動することで段差部分を通過できることが 確認できた.

\subsection{T字分忮管の走行英験}

内径 $79 \mathrm{~mm}$ のアクリル管を 3 本用意し, 図 8 に示寸 $\mathrm{T}$ 字 分岐実験用走行管を製作した。ロボットの前部ブレーキ機構 は，加える圧力を制御することにより，屈曲方向を決定する ことができる，そのため，ジョイスティックを用いて，ロボ ットの操作者が簡単に屈曲方向を決めることができる。試作 したロボットは, 内径 $79 \mathrm{~mm}$ のアクリル管から構成される T 字分岐点において，希望する方向に進入し走行できることが 確認できた。

\section{5. 結 言}

（1）内径の異なる管や $\mathrm{T}$ 字分岐管の通過ができるロボット を実現するため，へビの管内や縦穴等の移動方法であ るアコーディオン運動を模倣した管内走行ロボットを 試作した。

（2）試作した管内走行ロボットは，屈曲できるアクチュエ 一夕から構成される前後のブレーキ機構と, 変位を得 るための駆動機構である中心のベローズから構成され る.

（3）基本走行特性として，内径 $54 \mathrm{~mm}$ から $90 \mathrm{~mm}$ のアクリ ル管内での走行が確認でき，本ロボットの配管適応範 囲がわかった。走行速度は管の内径に依存せず，平均 $24 \mathrm{~mm} / \mathrm{s}$ であることもわかった。

（4）ロボットの適応範囲内の配管を組み合わせた内径の異 なる箇所が存在する管の走行が確認できた。

（5）前後のブレーキ機構の動作タイミングを制御すること により， $\mathrm{T}$ 字分岐管において希望する方向に走行でき ることが確認できた。

\section{参考文献}

[1] 大野学，加藤重雄：小径管内長距離走行用ミミズ型検查ロボッ 卜に関する研究（三体節式移動ロボットの開発とその基本性 能), 精密工学会誌, Vol. 71, No. 5 pp. 606-612

[2] Manabu ONO, Toshiaki HAMANO and Shigeo KATO: Modeling and Fabrication of a Mobile Inspection MicrorobotDriven by

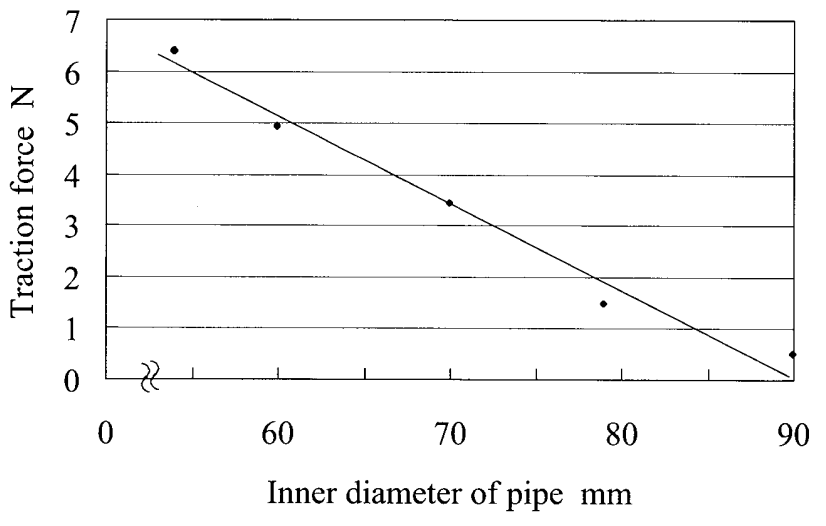

Fig. 6 Traction force characteristics

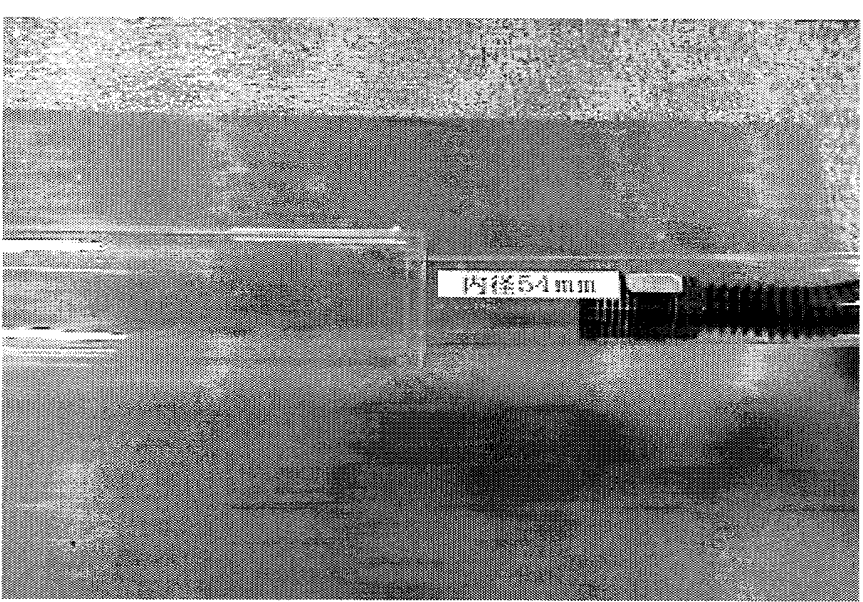

Fig. 7 Different diameter pipeline

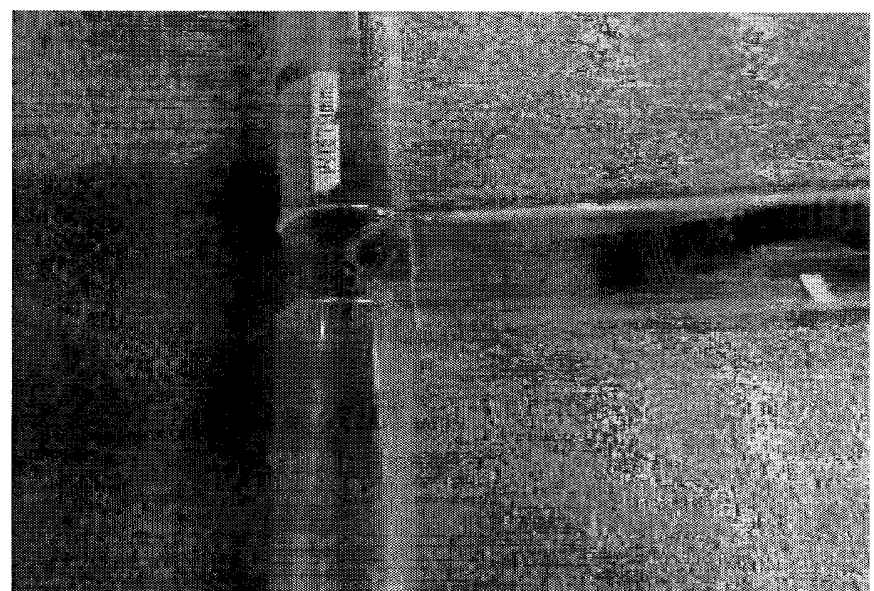

Fig. $8 \mathrm{~T}$ junction pipeline

Pneumatic Bellows Actuator for Long Pipes, Journal of Robotics and Mechatoronics Vol. 18, No. 1, pp. 11-17

[3] 大野学, 浜野聡明, 松本裕一, 涌井陽介, 加藤重雄 : ヘビの動 きと棈造を模做した管内走行ロボットの試作, 日本機械学会東 北支部 第 43 期 秋期講演会講演椧文集, pp. 95-96, 2007

[4] 大野学, 伊藤周三, 加藤重雄 : へビの動きと構造を模做した管 内走行ロボットの走行特性, 平成 19 年秋期フルードパワー講 演会講演論文集 pp. 106-108 